\title{
Analysis and Simulation of Current-source Flyback Inverter with Efficient BCM Control Strategy
}

\author{
SALAM J. YAQOOB ${ }^{1}$, JAWAD K. RAHAM ${ }^{2 *}$, HASSAN A. SADIQ ${ }^{3}$ \\ ${ }^{1}$ Authority of the popular Crowd, Office of the Primer Minister, IRAQ \\ $2^{2 *, 3}$ Operating division department, the Ministry of Electricity, IRAQ
}

\begin{abstract}
The Flyback inverter is a single-stage power inverter which represent an attractive solution for photovoltaic (PV) grid-tied inverter application. The main advantages of a current-source flyback inverter are high power density and high efficiency due to its small, as well as low total harmonic distortion (THD) operation. However, a flyback topology works with Discontinuous Conduction Mode (DCM) control strategy has lower efficiency and poor THD values. In this paper, an efficient current-source flyback inverter topology works with Boundary Conduction Mode (BCM) control strategy is presented. Besides, an efficient incremental conductance (IC) maximum power point tracking (MPPT) is used to extract the maximum power from the PV module. To verify the proposed control a power simulator (PSIM) software is used. As a result, the simulation results indicates that the BCM control is more efficient than the DCM method for various weather conditions. Finally, the proposed BCM strategy is compared with DCM control in terms of THD and thus it is achieved lower THD contain in the injection current of grid.
\end{abstract}

Keywords: Current source flyback inverter, BCM control strategy, THD contain, PSIM software Received: March 6, 2021. Revised: September 12, 2021. Accepted: October 15, 2021. Published: November 8, 2021.

\section{Introduction}

In last decades, the interest in photovoltaic power systems has grown in response to more and more concerns for many countries in the world. The PV power systems provide significant contribution to reduce the polluting emissions due to the fact it represents one of renewable energy sources [1-3]. The grid-connected inverters that supply the power from the PV system to AC utility grid are becoming suitable more and more due to absence the battery cost. Furthermore, the grid-connected inverters can be widely acceptable by the residential and market application due to high reliability and easy-designed monitor system [4]. However, several ways to arrange the solar PV modules are used to provide sufficient PV power to the grid-connected inverter, and then this will influence the cost of installation and inverter efficiency. The micro-inverter technology, which is a combination of a single PV module integrated with single-phase interactive inverter. With many advantages, over conventional inverters, this topology is considered the popular solution for grid-connected inverters for PV systems. The grid-connected inverter topologies are classified into three main types depending on the location of decoupling capacitor, number of the power stages, and the presence or absence of the transformers [5-8]. In case of the grid-connected inverter, an electrolytic capacitor has been connected across DC input of the inverter with large capacitance in order to decouple the power. The PV grid-connected inverters can be classified into three types based on the power conversion stage, single stage inverter, dual stage inverter and multi-stage inverter. In case of single stage inverter, the decoupling capacitor is placed across input PV side while it connected across the DC link side in case of two, and multistage inverter between DC/DC converter and DC/AC inverter as shown in Fig.1.

In dual stage inverter, the low output voltage from the PV module is amplified to AC level utility grid voltage by the $\mathrm{DC} / \mathrm{DC}$ converter and this converter implements the maximum power tracking method (MPPT) [10-13]. After that, the DC/AC inverter converts the high $\mathrm{DC}$ voltage to $\mathrm{AC}$ voltage with grid level voltage which controls the $\mathrm{AC}$ 
injected current to the grid by means of pulse width modulation technique (PWM). Also, the multi stage inverter consists of DC/DC converter for each PV module to implement the MPPT and amplify the DC voltage level of the module $[14,15]$. So, this advantage provides a better control method for each $\mathrm{PV}$ module. Furthermore, DC/AC inverter is used to control the grid current and convert the DC voltage level to AC utility grid voltage level [16-18]. However, some inverters use a low frequency transformer (LFT) which is placed between DC/AC inverter and the grid, to step-up inverter voltage to the grid voltage level, this transformer is considered a poor efficient due to increasing in size, price, and weight as presented in $[19,20]$. On other the hand, most efficient inverters use a high frequency transformer (HFT) with DC/DC converter or $\mathrm{DC} / \mathrm{AC}$ inverter, to reduce price and weight [21-23]. Furthermore, in single stage inverter type flyback inverter, the specific DC power is converted directly to $\mathrm{AC}$ power; therefore, the $\mathrm{DC} / \mathrm{DC}$ converter is not required. Thus, this topology becomes simple and more efficient than the multiple stage inverter topology, where size and components would be saved [24-28].

Several studies were presented to propose the optimal control strategy for the flyback inverter such as in $[27,28]$, the authors have proposed DCM control strategy to control the flyback inverter with constant switching frequency. The proposed control is implemented practically in laboratory $120 \mathrm{~W}$ PV system with a low cost digital-analog control scheme. The results obtained in that work is good in terms of THD values but there is a drawback of lower efficiency and low output power. Authors in [29] were presented a simple and low cost Continuous Conduction Mode (CCM) control for the flyabck inverter. So, when the flyabck inverter operates with CCM the main problem in this strategy is the right half-plane (RHP) zero that occurs in CCM region operation which may cause poor power quality and higher THD in output current. Also, in [30] a new hybrid control strategy based on one phase DCM or two-phase DCM is done to obtain higher efficiency at light load and heavy load conditions, and by relying on this technique the switching losses were reduced. Therefore, the BCM control strategy is applied on the flyback converter to increase the output power level that is injected to the utility grid.

In this research the efficient BCM control strategy for the flyback inverter is presented. The proposed control is depended on the measuring the output transformer winding and used they to provide a variable frequency Pulse width modulation
(PWM) signals to the main switch of the flyabck inverter. Therefore, the complexity of the BCM strategy is reduced and then more efficient control strategy is achieved to obtain a higher output power to the grid with many benefits such as high power level, and low cost and lower THD values.

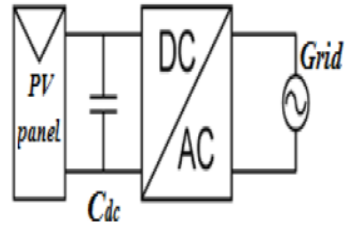

(a)

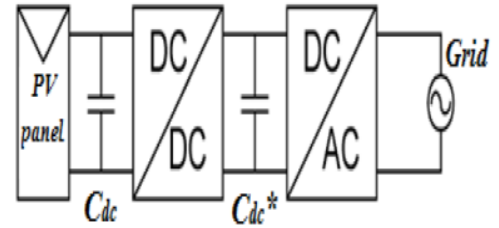

(b)
Figure 1 Grid connected inverter topologies

\section{Single-stage Flyback Inverter 2.1 Equivalent Circuit Structure}

The Flyback inverter topology is a single-stage inverter with a simple structure circuit. With many functions over multi stage inverters, the flyback PV micro-inverter provides DC/AC conversion with isolation between the input side and output side [24,25]. Also, the flyback topology works as current-source inverter without DC/DC converter, so it can be used with different PV systems [23]. These processes are implemented simultaneously. The topology transfers the output power from the PV modules to the grid through two secondary winding of a centre tap high frequency transformer alternatively during half time period of $\mathrm{AC}$ sinusoidal wave of utility grid as shown in Fig. 2 [23]. It formed from a decoupling capacitor $\mathrm{C}_{\mathrm{dc}}$, high frequency transformer (HFT) with single switch in input side, two switches in grid side with two diodes, and L-C output filter. The main switch, $\mathrm{S}_{1}$ operates with high switching frequency of 50 $\mathrm{kHz}$, while secondary switch, $\mathrm{S}_{2}$ and $\mathrm{S}_{3}$ operate with grid frequency of $50 \mathrm{~Hz}$.

Figure 3 shows the equivalent circuit and operation modes of flyback inverter during one switching period can be summed as following:

Mode 1: if the one switch, $S_{1}$ is in ON state, the DC input voltage is impressed through the primary winding, and then it will store the required energy in magnetizing inductance of transformer, $\mathrm{L}_{\mathrm{m}}$ and cause the primary current ramps up to reached its maximum value. The other switches are OFF and the filter capacitor, $\mathrm{C}_{\mathrm{f}}$ is discharged to grid as shown in Fig. 3b. Mode 2: When the, $S_{1}$ is OFF state, the stored energy in magnetizing inductance will be released to $\mathrm{AC}$ utility grid that has positive polarity 
by turning $\mathrm{ON}$ the switches of $\mathrm{S}_{2}$ and $\mathrm{D}_{1}$ and all other switches stay in OFF state as presented in Fig.3c.

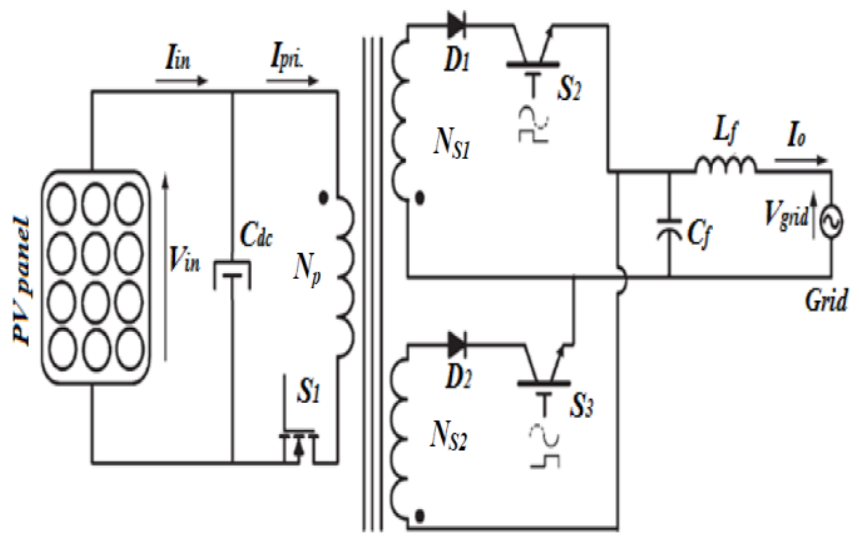

Figure 2 single stage flyback inverter topology

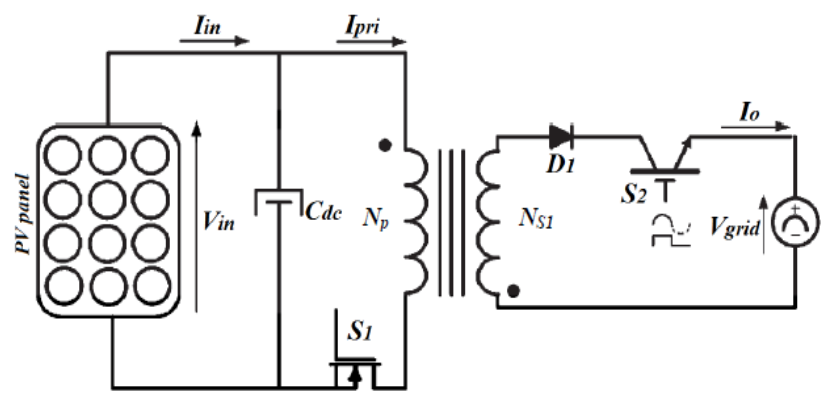

(a)

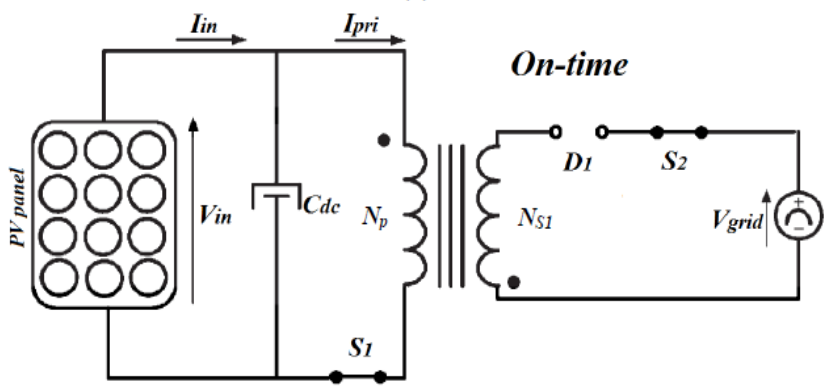

(b)

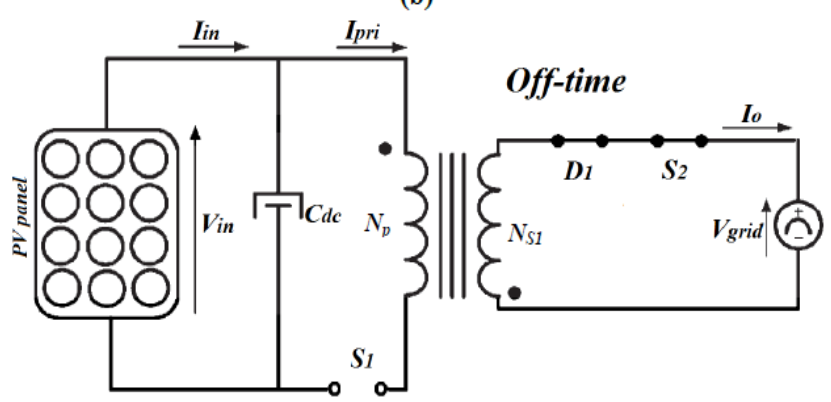

(c)

Fig.3.equivelnt circuit of flyback inverter (a) during grid line half cycle (b) when $S_{1}$ in ON state (c) when $S_{1}$ in OFF state

\subsection{Analysis of Flyback BCM operation}

The basic equations of flyback inverter operated with BCM control is derived from the analysis of the same circuit in DCM control operation as presented in [23]. Based on equivalent flyback circuit, the total switching period of each time can be expressed as,

$T_{S}(t)=T_{o n}(t)+T_{o f f}(t)$

Where $T_{o n}(t)$ is the ON tiem of the main MOSFET, and $T_{o f f}(t)$ is the OFF time of the main MOSFET. The main advanteg of the BCM control is operated with variable switching frequency $f_{s}$. Due to the primary current is a sinusoidal wave form, so the OFF time and ON time should be matched to sure the circuit is operated with $\mathrm{BCM}$. Therefore, the $\mathrm{ON}$ time of the MOSFET can be written as $[23,28]$ :

$$
T_{\text {on }}(t)=T_{\text {on,peak }} \sin \omega t
$$

Also, $T_{\text {on,peak }}(t)$ is the interval value referring to the switching period that occurs at $\omega t=\frac{\pi}{2}$. In other the hand, the maximum OFF time period $T_{\text {off,peak }}$ can be calculated from the following equation [23]:

$$
T_{\text {off }, \text { peak }}=\frac{\lambda}{N} T_{\text {on,peak }}
$$

Where $\lambda=\frac{\mathrm{V}_{\text {in }}}{\widehat{\mathrm{V}}_{\mathrm{g}}}$, and $N$ is the transformer turns ratio. Also, the $\mathrm{V}_{\text {in }}$ is the de input voltage (PV volatge), and $\widehat{V}_{g}$ is the peak grid voltage. In addition, from the above equation the total switching period can be calculated from the following equation:

$$
\begin{aligned}
& T_{s}(t)=T_{o n}(t)+T_{o f f}(t) \\
& T_{s}(t)=\left(\frac{\lambda}{N}+\sin \omega t\right) T_{\text {on,peak }}
\end{aligned}
$$

According to Eq. (5), the minimum and maximum switching frequency in BCM strategy should be determined as following:

$$
\begin{aligned}
& f_{s, \min }=\frac{1}{T_{s, \max }}=\left.\frac{1}{T_{s}}\right|_{\omega t=\frac{\pi}{2}}=\frac{1}{\left(\frac{\lambda}{N}+1\right) T_{\text {on,peak }}} \\
& f_{s, \max }=\frac{1}{T_{s, \min }}=\left.\frac{1}{T_{s}}\right|_{\omega t=0}=\frac{N}{\lambda T_{\text {on,peak }}}
\end{aligned}
$$

The output power transferred to the grid can be written as in [23],

$$
P_{o}=\frac{0.5 V_{\text {in }}}{L_{m}} \quad T_{\text {on,peak }} F\left(\frac{\lambda}{N}\right)
$$


According to the procedure presented in [23], the function can be calculated analytically from the following formula:

$F\left(\frac{\lambda}{N}\right)=\frac{2}{\pi}-\frac{\lambda}{N}+\left(\frac{\lambda}{N}\right)^{2} S\left(\frac{\lambda}{N}\right)$

Where $S\left(\frac{\lambda}{N}\right)$ can be expresed as in $[23,27]$ :

$S\left(\frac{\lambda}{N}\right)=\frac{1}{\pi} \int_{0}^{\pi} \frac{d \theta}{\frac{\lambda}{N}+\sin \theta}$

Using Eqs. (8-10), the output power can be written as,

$$
\begin{aligned}
P_{o}=g_{s} V_{g, r m s}^{2} & =g_{l \_a v g} \frac{\lambda}{\left(\frac{\lambda}{N}+\frac{2}{\pi}\right)}\left[\frac{2}{\pi}-\frac{\lambda}{N}\right. \\
& \left.+\left(\frac{\lambda}{N}\right)^{2} S\left(\frac{\lambda}{N}\right)\right] V_{g, r m s}^{2}
\end{aligned}
$$

Leading the following relation between $g_{s}$ and

$g_{l_{-} a v g}$,

$$
\frac{g_{s}}{g_{l_{-} a v g}}=\frac{\lambda}{\left(\frac{\lambda}{N}+\frac{2}{\pi}\right)}\left[\frac{2}{\pi}-\frac{\lambda}{N}+\left(\frac{\lambda}{N}\right)^{2} S\left(\frac{\lambda}{N}\right)\right]
$$

Where $g_{l_{-} a v g}=\frac{1}{f_{s_{-} a v g} L_{m}}$. In addition, The average switching frequency $f_{S_{-} a v g}$ can be wrriten as in [23],

$$
f_{\text {s_avg }}=\frac{1}{T_{\text {on,peak }}\left(\frac{\lambda}{N}+\frac{2}{\pi}\right)}
$$

In order to test the flyback inverter performance, the value of the $\lambda$ parameter is very important. Figure 3 presented $\left(g_{s} / g_{l_{-} a v g}\right)$ as function of $N$ with $\lambda$ parameter. So, the power transferred to the grid in BCM is higher than that transferred in DCM strategy for the same values of $N$ and $\lambda$ [23].

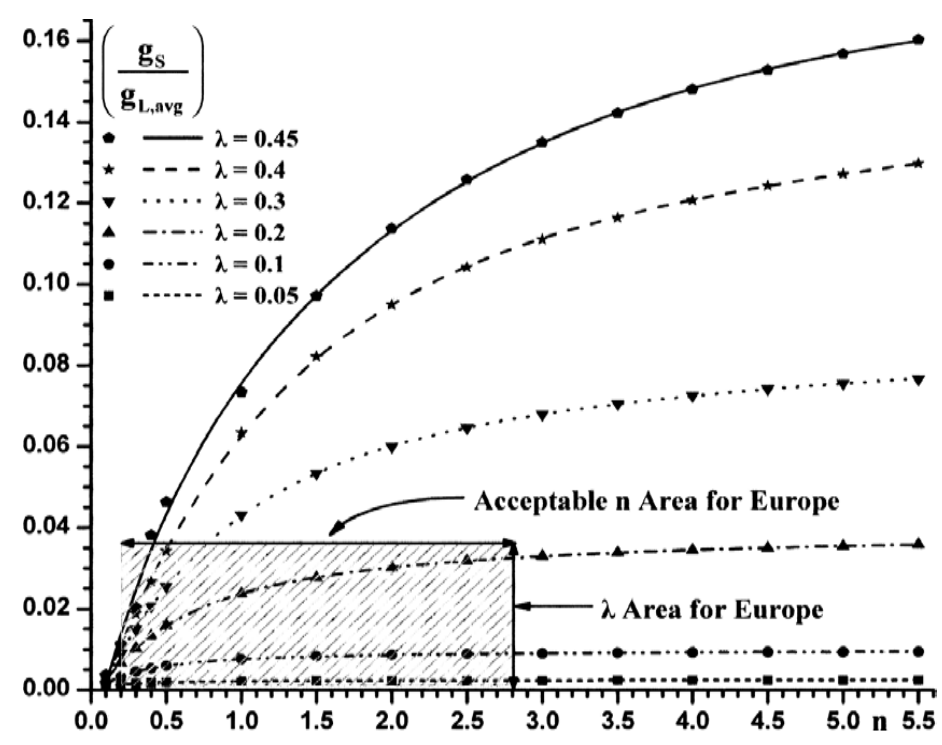

Figure 4. $\left(g_{s} / g_{l \_a v g}\right)$ as function of $N$ with $\lambda$ parameter in BCM control strategy [23]

\section{Proposed BCM Control Strategy}

Comparison with DCM control strategy, the control scheme of the BCM strategy is more complex than DCM due to it operated with a variable switching frequency. But the DCM control strategy is used only for low power applications about $100 \mathrm{~W}$. Another drawback point in DCM control, the inverter circuit is very critical because of the higher value of the primary winding current which may lead the inverter enter in CCM operation under heavy load conditions. therefore, the BCM control is considered more efficient which is the best solution for the flyback topology in high power levels above $200 \mathrm{~W}$. in this paper, the BCM control strategy is used to control the flyback circuit switches. Figure 5 shows the proposed block diagram of BCM control strategy. As observed, the optimal power from the PV module is extracted using incremental conductance (IC) method. The maximum power point (MPP) is obtained by tracking the PV voltage during a PI controller. Moreover, the grid voltage is sensed and the full rectified is obtained to compare it with the optimal value of the PV voltage. Besides, the output transformer winding currents $I_{01}$ and $I_{02}$ are sensed to form the total output current that compared with ground level. Then, this signal is provided to logic AND gate. The primary MOSFET current $I_{S 1}$ is fed across the PWM modulator to sure and enhanced primary current reference value to control main MOSFET. Moreover, the real primary current is compared with its reference value instead of using a fixed switching saw-tooth signal as presented in 
traditional DCM control. The main contribution of this control is the control of the main MOSFET switch under variable switching frequency. In addition, the proposed control strategy is tested under different weather conditions to prove the performance.

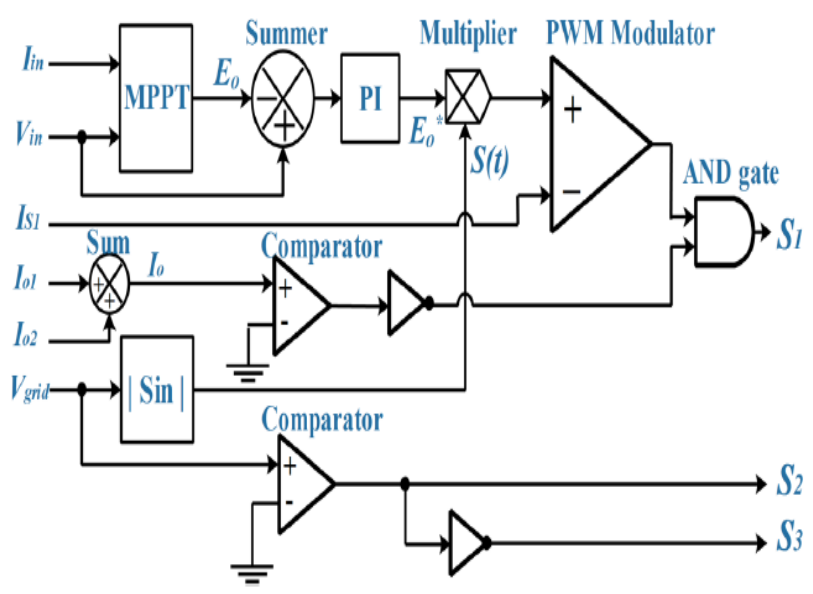

Figure 5. proposed BCM control strategy for flyback topology

\section{Simulation Results and Discussion}

To prove the proposed BCM flyback inverter, the entire system has simulated using PSIM software. Table 1 presents the parameters of the proposed system circuit. In order to test the performance of the proposed control, solar irradiance profile with fast changing is applied. Figure 8 presents the simulation results of PV module under step change in solar irradiance. As observed, the PV voltage panel, $\mathrm{V}_{\mathrm{pv}}=35 \mathrm{~V}$ with a little of ripple about, $\Delta_{\mathrm{V}}=1.5 \mathrm{~V}$. Also, this figure shows the PV module current, whose value $\mathrm{I}_{\mathrm{pv}}=$ $4.66 \mathrm{~A}$, and has small ripple of $\Delta_{\mathrm{i}}=0.1 \mathrm{~A}$ for the $\mathrm{PV}$ power, $\mathrm{P}_{\mathrm{pv}}=200 \mathrm{~W}$. It clear that, when the irradiance level step down from $G=1000 \mathrm{~W} / \mathrm{m}^{2}$ to $\mathrm{G}=400 \mathrm{~W} / \mathrm{m}^{2}$, the PV power is decreased from $200 \mathrm{~W}$ to $80 \mathrm{~W}$ at constant temperature $\mathrm{T}=25^{\circ} \mathrm{C}$. In addition, the time response for both grid voltage and injected current o the grid can see in Fig. 7. As seen, when irradiance value is changed from $1000 \mathrm{~W} / \mathrm{m}^{2}$ to $400 \mathrm{~W} / \mathrm{m}^{2}$, the grid current is decreased to a certain value while the inverter keeps the voltage in utility grid level, also the primary current is decreased during this period. Moreover, the injected current has a good power factor PF regulation with a well THD value about 2.97 at $200 \mathrm{~W}$. The proposed control maintains the THD and PF at acceptable values during the changing in irradiance. Figure 8 shows the simulation results for all currents passed through the transformer at steady state conditions. As observed, the primary current of the main MOSFET has a rectified sine wave due to SPWM, its peak value $\hat{I}_{p}=29 \mathrm{~A}$. Figure $8 \mathrm{~b}$ shows the first secondary current, that flow during, $\mathrm{S}_{2}$ and $\mathrm{D}_{1}$ at the positive half cycle of the grid voltage with maximum value of $\hat{\mathrm{I}}_{\mathrm{s} 1}=3.4 \mathrm{~A}$. Figure 8 -c shows the second secondary current that flow during $S_{3}$ and $D_{2}$ at the negative half cycle of the grid voltage with peak value of $\hat{I}_{\mathrm{s} 2}=-3.4 \mathrm{~A}$. Also, Fig. 8-d presents the total secondary current, $\mathrm{i}_{\mathrm{S}}$ which represents the output current that is injected to the utility grid without C-L filter. Besides, the total secondary has RMS value is $\mathrm{I}_{\mathrm{s}, \mathrm{rms}}=0.92 \mathrm{~A}$. Figure 9 reports the current waveform fed to the utility grid from the proposed inverter with L-C filter with RMS value of $0.7 \mathrm{~A}$. as observed, the robustness of the proposed BCM control can be seen in maintain the injection current in-phase with the grid always with unity power factor regulation of 0.99 and $\mathrm{THD}=$ $2.96 \%$

Table1. Simulation parameters used in the proposed work.

\begin{tabular}{|l|l|c|}
\hline Parameter & Value & Unit \\
\hline Maximum output power, $P_{o}$ & 200 & $W$ \\
\hline Output voltage, $V_{g}$ & 220 & $V$ \\
\hline PV voltage range, $V_{p v}$ & $30-37$ & $V$ \\
\hline Switching frequency, $f_{s}$ & 50 & $k H z$ \\
\hline Maximum duty cycle $d$ & 0.6 & - \\
\hline Filter Capacitor $C_{f}$ & 1.4 & $\mu F$ \\
\hline Filter inductor $L_{f}$ & 2 & $m H$ \\
\hline
\end{tabular}

The grid current, $I_{g}$ is mainly proportional to the value of solar irradiance. For this reason, high grid current is achieved in high solar radiation, this leads to well values of PF and THD. On other hand, poor values of PF and THD are obtained during low solar irradiance. The $\mathrm{PF}$ is near unity at high power values. The low values of THD $(<5 \%)$ is achieved in proposed micro-inverter. Besides, at low output power, the PF is low, due to the output filter capacitor. As a result, when the transferred power to grid is high, the capacitive load becomes a small fraction of the total load and it has a little effect on the PF, but at low power levels, this capacitive load can result in $\mathrm{PF}$ as low. In order to compare the performance of the proposed BCM control strategy with other control strategy used recently, a comparison based THD values is obtained as 
presented in Table 3. The proposed control strategy shows good values in terms of THD content where a well value is indicated in high power rating.

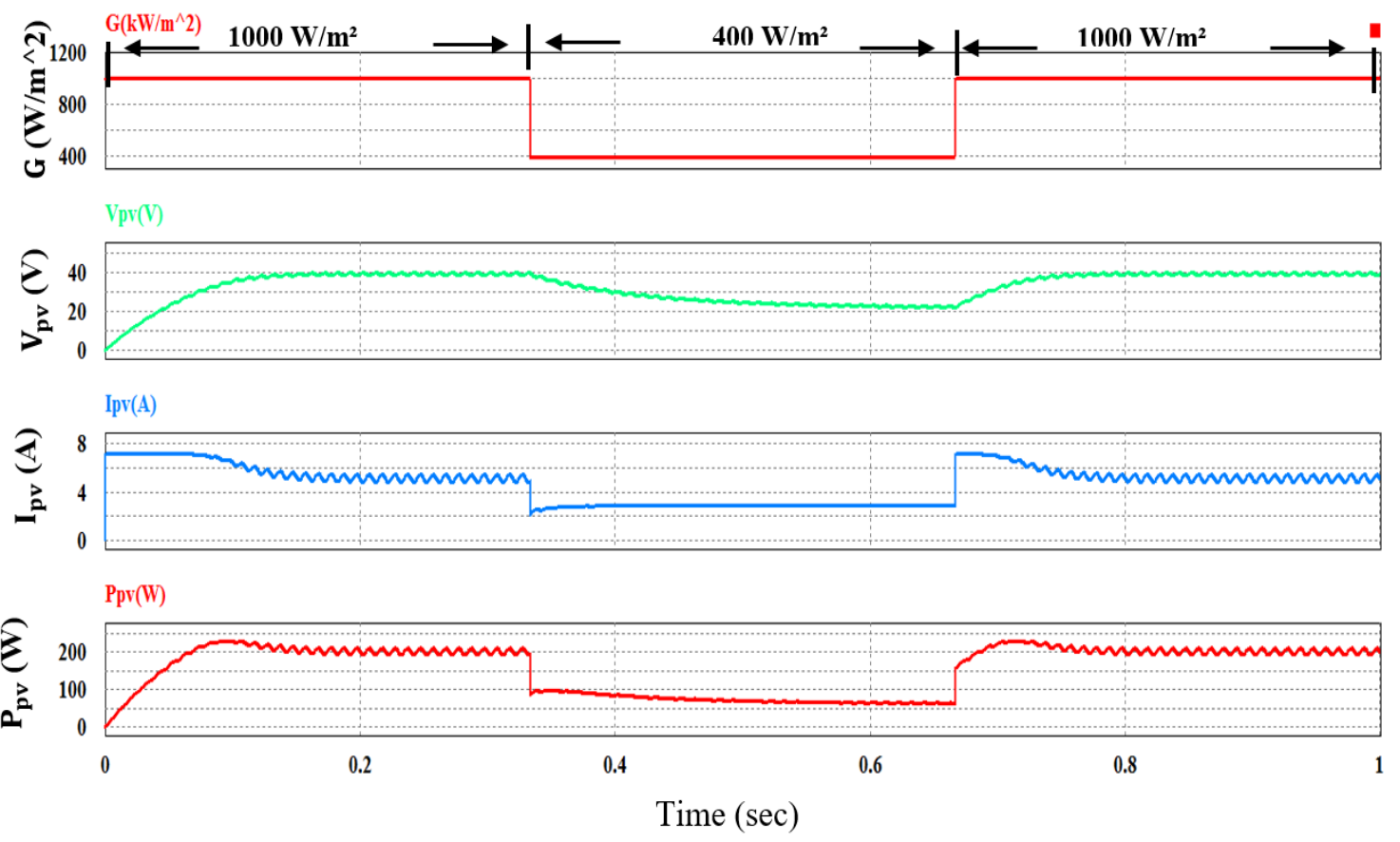

Figure 6 Simulation results of the proposed control for flyback inverter.

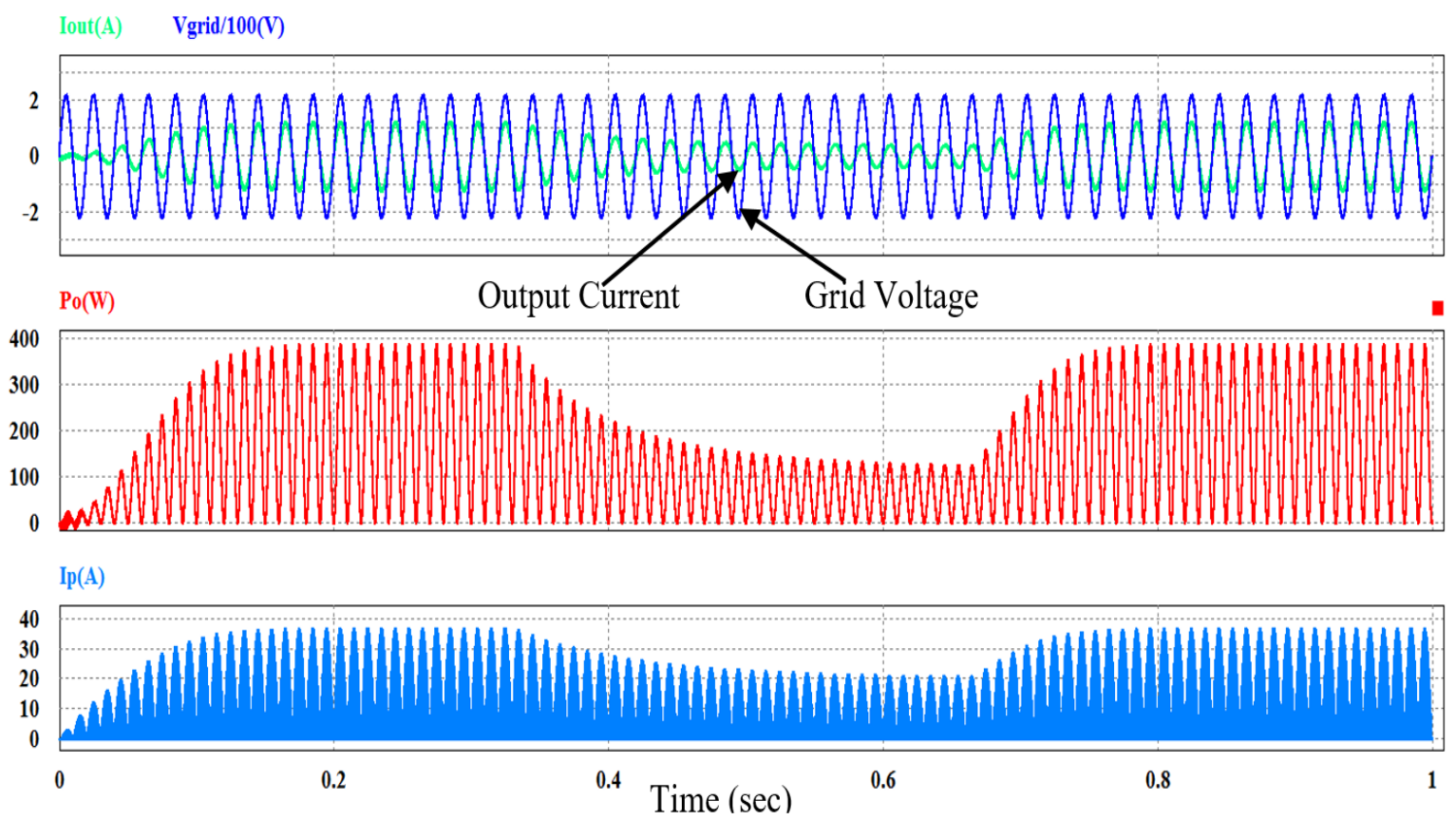

Figure 7 proposed inverter results during fast changing in irradiance. Top to bottom: grid voltage with grid current, transferred power to the grid, the main MOSFET current (primary). 


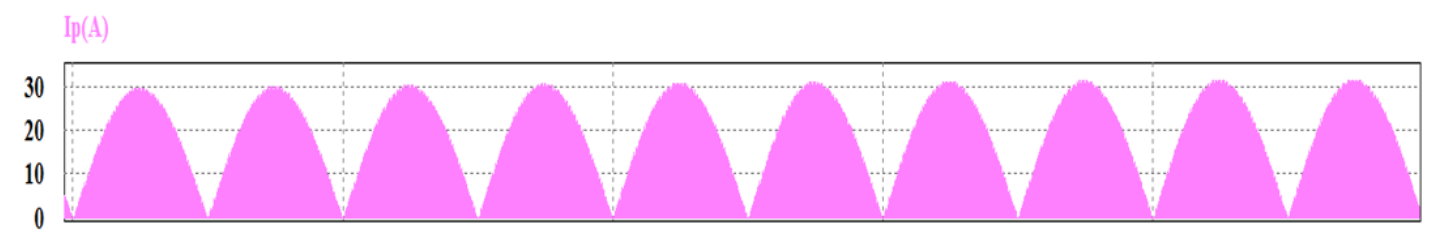

(a)

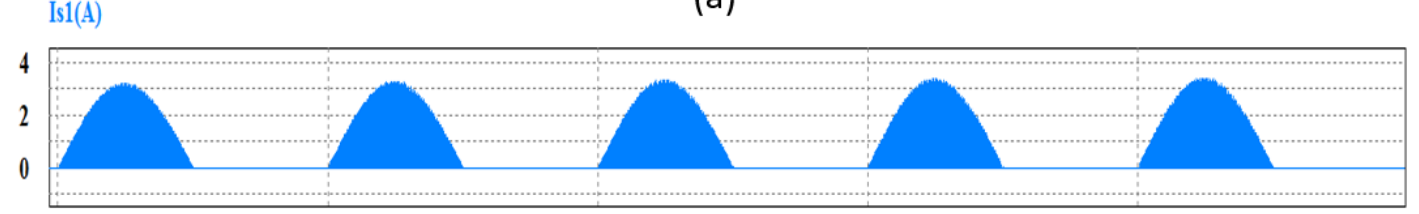

(b)

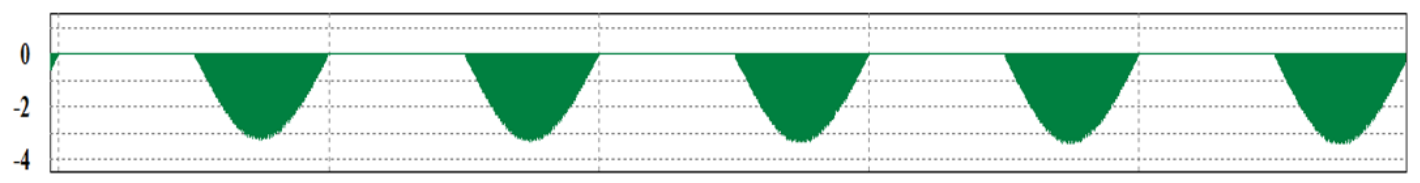

(c)

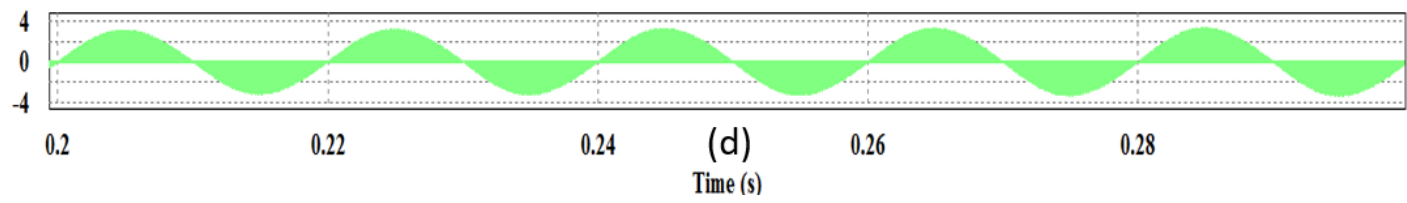

Figure 8 All currents passed through the primary and secondary winding (a) primary winding current (b) secondary current in one winding (c) secondary current in other winding (d) overall secondary current injected to grid before filter.

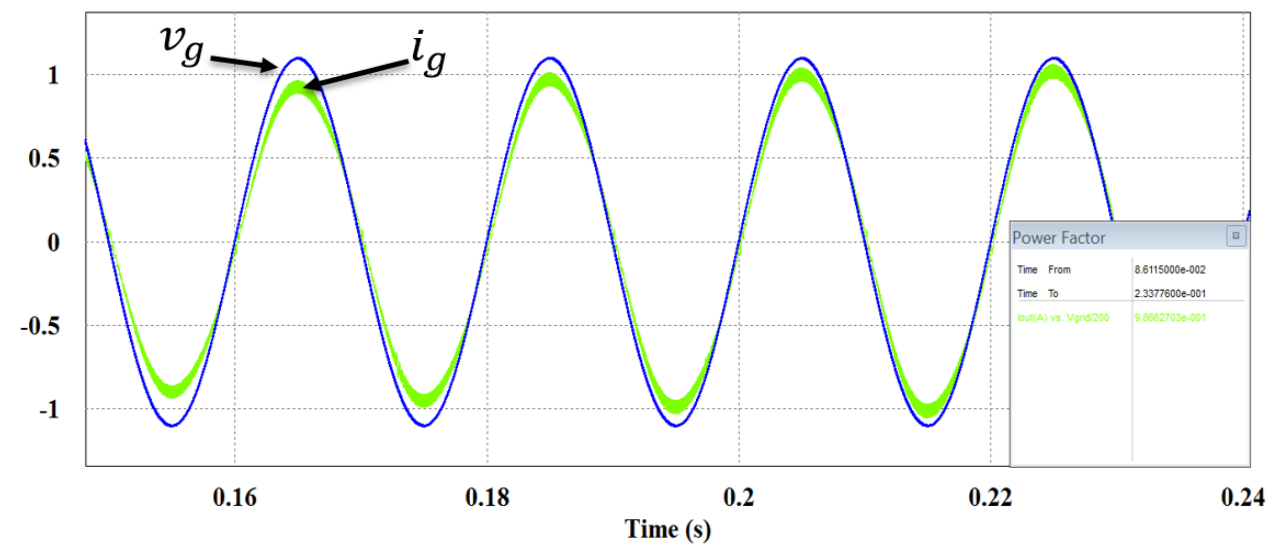

Figure 9 injection current to the grid at irradiance $1000 \mathrm{~W} / \mathrm{m}^{2}$ and fixed temperature $\mathrm{T}=25 \mathrm{C}$.

Table 2. Comparison of THD values between results obtained by other authors and proposed work.

\begin{tabular}{|l|l|l|l|l|l|}
\hline Power (W) & $\mathbf{2 0}$ & $\mathbf{4 0}$ & $\mathbf{6 0}$ & $\mathbf{8 0}$ & $\mathbf{1 0 0}$ \\
\hline THD in [27] & 6.32 & 5.04 & 4 & 3.8 & 3.2 \\
\hline $\begin{array}{l}\text { Proposed } \\
\text { THD }\end{array}$ & 6.4 & 4.9 & 3.8 & 3 & 2.97 \\
\hline
\end{tabular}

\section{Conclusion}

In this work, an efficient BCM control strategy for a current-source flyback inverter topology is proposed. First, the equivalent circuit and theoretical analysis of the flyback inverter is studied to show the principle action of the flyabck circuit under BCM control strategy. Second, the proposed $\mathrm{BCM}$ control circuit is designed including MPPT which is used to extract the optimal power from the PV module using incremental conductance (IC) method. Moreover, the main engine of the 
proposed control strategy is combined the secondary transformer winding currents to obtain the actual output current during PWM comparator. Also, the actual primary current is compared with its reference value instead of using a fixed switching saw-tooth signal as presented in traditional DCM control strategy. As a result, the main MOSFET switch has been controlled under variable switching frequency. In order to test the performance of the proposed control, the results have been compared with that obtained by other authors. Comparison show that the proposed control strategy has good values of THD content and power factor regulation in injection current especially in high power levels.

\section{References}

[1] Evans, A., Strezov, V., \& Evans, T. J. (2009). Assessment of sustainability indicators for renewable energy technologies. Renewable and sustainable energy reviews, 13(5), 1082-1088.

[2] Frondel, M., Ritter, N., Schmidt, C. M., \& Vance, C. (2010). Economic impacts from the promotion of renewable energy technologies: The German experience. Energy Policy, 38(8), 4048-4056.

[3] Mahela, O. P., \& Shaik, A. G. (2017). Comprehensive overview of grid interfaced solar photovoltaic systems. Renewable and Sustainable Energy Reviews, 68, 316-332.

[4] M. G. Villalva, J. R. Gazoli, and E. R. Filho, "Comprehensive Approach to Modeling and Simulation of Photovoltaic Arrays," IEEE Transactions on Power Electronics, vol. 42, no. 5, May, 2009.

[5] S. Öztürk and I. Çadirci, "DSPIC Microcontroller Based Implementation of A Flyback PV Micro-Inverter Using Direct Digital Synthesis," IEEE Energy Conversion Congress and Exposition (ECCE), pp. 3426 3433, Denver, Sep.2013.

[6] H. A.Sher, K. E. Addoweesh and K. Al-Haddad, "Performance Enhancement of a Flyback Photovoltaic Inverter using Hybrid Maximum Power Point Tracking," IEEE $1^{\text {st }}$ Annual Conference in Industrial Electronics Society (IECON), pp. 005369 - 005373, Yokohama, Nov. (9-12). 2015.

[7] M. Khalilian, M. M. Rad, E. Adib, and H. Farzan e hfard,"New Single-Stage Soft Switching Flyback Inverter for AC Module Application with Simple Circuit," IEEE, $6^{\text {th }}$ International Power Electronics Drive Systems and Technologies Conference (PEDSTC), pp. 41-
46, 3-4, Tehran, February. 2015.

[8] J.Liao, J. Su, L. Chang, and J. Lai, “A Mixed Decoupling Power Method for Single-Phase Grid-connected Inverters," IEEE $7^{\text {th }}$ international Symposium on Power Electronics for Distributed Generator Systems (PEDG), pp.1-5, Jun. 2016.

[9] Chen, L., Amirahmadi, A., Zhang, Q., Kutkut, N., \& Batarseh, I. (2013). Design and implementation of three-phase two-stage gridconnected module integrated converter. IEEE Transactions on Power Electronics, 29(8), 3881-3892.

[10] Liu, J., Cheng, S., Liu, Y., \& Shen, A. (2019). FCS- MPC for a single- phase two- stage grid- connected PV inverter. IET Power Electronics, 12(4), 915-922.

[11] Altin, N., Ozdemir, S., Komurcugil, H., Sefa, I., \& Biricik, S. (2018, April). Two-stage gridconnected inverter for PV systems. In 2018 IEEE 12th International Conference on Compatibility, Power Electronics and Power Engineering (CPE-POWERENG 2018) (pp. 16). IEEE.

[12] Trujillo, C. L., Santamaría, F., \& Gaona, E. E. (2016). Modeling and testing of two-stage gridconnected photovoltaic microinverters. Renewable energy, 99, 533-542.

[13] Dong, D., Cvetkovic, I., Boroyevich, D., Zhang , W., Wang, R., \& Mattavelli, P. (2012). Gridinterface bidirectional converter for residential DC distribution systems-Part one: Highdensity

twostage topology. IEEE Transactions on Power El ectronics, 28(4), 1655-1666.

[14] Prasad, B. S., Jain, S., \& Agarwal, V. (2008). Universal single-stage grid-connected inverter. IEEE Transactions on Energy Conversion, 23(1), 128-137.

[15] Hu, Y., Cao, W., Ji, B., Si, J., \& Chen, X. (2015). New multi-stage DC-DC converters for grid-connected photovoltaic systems. Renewable energy, 74, 247-254.

[16] Changizian, M., Zakerian, A., \& Saleki, A. (2017). Three-phase multistage system (DCAC-DC-AC) for connecting solar cells to the grid. Emerging Science Journal, 1(3), 135-144.

[17] Yaqoob, S. J., \& Obed, A. A. (2021). An Efficient Grid-tied Flyback Micro-inverter with DCM Control Strategy. Journal of Techniques, 3(1), 74-84.

[18] Ma, L., Tang, F., Zhou, F., Jin, X., \& Tong, Y. (2008, November). Leakage current analysis of a single-phase transformer-less PV inverter connected to the grid. In 2008 IEEE 
International Conference on Sustainable Energy Technologies (pp. 285-289). IEEE.

[19] Da Silva, R. L., Borges, V. L. F., Possamai, C. E., \& Barbi, I. (2020). Solid-state transformer for power distribution grid based on a hybrid switched-capacitor LLC-SRC converter: Analysis, design, and experimentation. IEEE Access, 8, 141182-141207.

[20] Shi, Y., Li, R., Xue, Y., \& Li, H. (2015). Highfrequency-link-based grid-tied PV system with small DC-link capacitor and low-frequency ripple-free maximum power point tracking. IEEE Transactions on Power Electronics, 31(1), 328-339.

[21] A. C. Nanakos, E. C. Tatakis, and N. P. Papanikolaou, "A Weighted-efficiencyOriented Design Methodology of Flyback Inverter for ac Photovoltaic Modules," IEEE Trans. Power Electron., vol. 27, no. 7, pp. 3221- 3233, Jul. 2012.

[22] M. Gao, M. Chen, C. Zhang, and Z. Qian, "Analysis and Implementation of An Improved Flyback Inverter for Photovoltaic ac Module Applications," IEEE Trans. Power Electron., vol. 29, no. 7, pp. 3428-3444, Jul. 2014.

[23] A. Ch. Kyristis, E. C. Tatakis, and N.P. Papanikolaou, "Optimum Design of the Current-Source Flyback Inverter for Decentralized Grid-connected Photovoltaic Systems," IEEE Transactions on Energy Conversion, vol.23, no.1, pp.281-293, Mar. 2008.

[24] N. Sukesh, M. Pahlevaninezhad, and P. K. Jain, "Analysis and Implementation of a SingleStage Flyback PV Microinverter With Soft Switching," IEEE Trans. Ind. Electron., vol. 61, no. 4, pp. 1819-1833. April.2014.

[25] H. Hu, S. Harb, N. H. Kutkut, Z. J. Shen, and I. Batarseh, "A Single Stage Micro-inverter without Using Electrolytic Capacitors," IEEE Transactions on Power Electronics, vol. 28, no. 6, pp. 2677 - 2687, Jun. 2013

[26] C. M. Lai, M. J. Yang, W. C. Liu, "ParallelOperated Single-Stage Flyback-Type SinglePhase Solar Micro-inverter," IEEE, International Conference in Intelligent Green Building and Smart Grid (IGBSG), pp. 1-5, Apr. 2014.

[27] Yaqoob, S. J., Obed, A., Zubo, R., Al-Yasir, Y. I., Fadhel, H., Mokryani, G., \& Abd-Alhameed, R. A. (2021). Flyback Photovoltaic MicroInverter with a Low Cost and Simple DigitalAnalog Control Scheme. Energies, 14(14), 4239.
[28] Salam J. Yaqoob, Adel A. Obed, "Photovoltaic Flyback Micro-inverter with Power Decoupling Technique," Indonesian Journal of Electrical Engineering and Computer Science (IJEECS), pp. 9-19,vol.15, no.1, July, 2019.

[29] Y. Li and R. Oruganti, "A Low Cost Flyback CCM Inverter for AC Module Application," IEEE Trans. Power Electron, vol.27, no.3, pp. 1295-1303, Mar 2012.

[30] G. C. Christidis, A. C. Nanakos and E.C. Tatakis, "Hybrid Discontinuous/Boundary Conduction Mode of Flyback Microinverter for AC-PV Modules," IEEE Transactions on Power Electronics, vol. 31, no. 6, pp.41954205, June, 2016.

\section{Creative Commons Attribution License 4.0 (Attribution 4.0 International, CC BY 4.0)}

This article is published under the terms of the Creative Commons Attribution License 4.0

https://creativecommons.org/licenses/by/4.0/deed.en_US 